\title{
Trade and the Timing of Elections
}

\author{
Mark Andreas Kayser ${ }^{\dagger}$
}

27 January 2005

\begin{abstract}
${ }^{*}$
Do trade-transmitted international business cycles affect the timing of national elections? This paper shows that exports do not differ from domestic demand in inviting opportunistic governments to call elections, especially as their terms mature. Further analysis confirms two ancillary implications of this relationship: (a) that clusters of countries tend to hold elections in periods of international economic expansion and (b) that national election cycles, much like business cycles, have become more correlated over time, most prominently in Europe. The findings in this paper raise implications for continued economic integration: freer movement of goods, services, and capital may imply more correlated business and, by extension, election cycles.
\end{abstract}

\footnotetext{
† Assistant Professor, Department of Political Science, University of Rochester. Email: mark.kayser@rochester.edu. * I gratefully acknowledge constructive comments from Kathleen Bawn, Neal Beck, Melissa Chiu, Bill Clark, Geoffrey Garrett, Miriam Golden, David Karol, Tasos Kalandrakis, Luke Keele, John Londregan, Harvey Palmer, Ronald Rogowski, and Alastair Smith. Thanks also to Tanya Bagashka and Subhasish Ray for valuable research assistance and to Nuffield College, Oxford for their support for part of this research via a Postdoctoral Prize Research Fellowship. All errors are irrefutably mine. Previous versions of this paper have been presented at UCLA, Yale, Princeton and New York University.
} 
When you think economics, think elections;

When you think elections, think economics.

-Edward Tufte, 1978, p. 65

Politicians, journalists, and scholars alike commonly believe that those governments that can call elections while the economy is expanding, do so. Economic expansions - or anticipated contractions - invite early elections in the majority of parliamentary democracies that permit them. Several studies confirm that governments time elections to coincide with the performance of their national economies (Palmer and Whitten 2000, Roper and Andrews 2002, Smith 2003). Yet, given high levels of international economic integration, especially among the advanced economies of Western Europe, is it possible for governments to distinguish between domestically and externally generated expansions? Or, alternatively, do foreign economic expansions influence the timing of domestic elections? This paper argues the latter: Internationally transmitted economic cycles influence national election timing.

There is no doubt that advanced industrial economies are highly integrated into the international economy. Exports now constitute over half of gross domestic product (GDP) in the most trade-exposed countries; governments have ceded or struggled to maintain monetary autonomy in an era of flexible exchange rates and mobile capital; exchange rates have been carefully managed (and now fixed) in many regions such as the European Union; and at the same time international capital flows of portfolio and direct investment have reached record levels. By most indices, by the late 1990s international economic integration had surpassed its previous pre- First World War apex (Bordo, Eichengreen, Douglas 1999). In Western Europe observers have even declared the emergence of a region-wide business cycle in by 1990s (Artis and Zhang 1997, 1999). Such levels of integration have spurred considerable interest in the policy consequences of economic interdependence - primarily on how the international economy may or may not constrain national economic, social welfare, and labor policy - but little research has emerged on the consequences for politics per se. This paper argues that international economic integrations does matter for at least one political process: the opportunistic 
timing of elections. The argument is simple. In economically integrated countries, internationally generated economic fluctuations to not differ from their domestically generated counterparts in inviting opportunistic elections. Once about half of their maximum terms have passed (cf. Kayser 2005), governments, believing that economic performance affects the vote, time elections to capitalize on exceptional booms or preempt anticipated downturns. Concern about the domestic or foreign provenance of an expansion does not enter their timing calculus.

Until rather recently, opportunistic election timing itself has been largely neglected, only considered in the context of a refinement to the political business cycle (e.g., Ito and Park 1988; Chowdurry 1993) or as a residual in the government stability and duration literature (cf., Warwick 1994). More current interest in election timing per se, however, has begun to redress this shortcoming. We now know that opportunistic election timing, especially in the latter part of a government's term, (a) prevails in the majority of advanced industrial democracies and, given the popularity of parliamentary type arrangements, most likely in the majority of all democracies, ${ }^{1}$ (b) occurs under both single-party (Balke 1990, Roper and Andrews 2002; Kayser 2005) and coalition governments (Lupia and Strom 1995, Diermeier and Stevenson 2000), (c) varies in government strength and prime ministerial dissolution-autonomy (Strom and Swindle 2002), (d) reduces government popularity (Smith 2003 but see Blais et al 2004), and (e) responds to different macroeconomic variables under left and right-wing governments (Palmer and Whitten 2000). In short, institutions and partisanship matter but opportunistic election calling happens.

The occurrence of opportunistic election timing, however, does not necessarily make for simple empirical testing. Seemingly mundane estimation problems like determining the direction of causality between economic performance and election timing pose a difficulty. Scholars who endogenize both election timing and economic manipulation have found that causality runs in both directions (e.g., Cargill and

\footnotetext{
${ }^{1}$ This paper identifies 13 of 24 OECD members in 1990 as premier timing; (Przeworski et al. 2000) list 37 of 59 democracies in 1990 as parliamentary, a government form that typically provides governments with great leeway in choosing when to dissolve parliament for elections.
} 
Hutchinson 1991 and Ito 1990, both for Japan) albeit sometimes only toward timing

(Chowdhurry 1993, for India). The use of exports as the measure of cross-border influence in this article is explicitly intended to preclude concerns about reverse causality. Barring pre-election currency devaluations, which would self-defeatingly reduce short-term real income, ${ }^{2}$ there is no way by which governments can spur trade expansions quickly enough to justify endogeneity concerns in quarterly data. ${ }^{3}$ In short, because they allay concerns about reverse causality, exports seem an ideal tool to use in predicting opportunistic elections as a function of one transmitter of international economic cycles.

Another way to establish an effect is through its consequences. One such consequence of opportunistic election timing in response to internationally transmitted economic cycles is the greater temporal clustering of elections among economically open countries with governments politically and constitutionally able to time their own elections. Already in 1978, Edward Tufte (ch. 3) noted a temporal clustering of elections among a small sample of industrial democracies but, reversing causality, he worried that exogenously occurring election clusters could cause politically induced cycles in the international economy. ${ }^{4}$ Thompson and Zuk (1983) soon refuted this idea, yet with the partial exception of Ito (1991) no one has considered the converse possibility, that

\footnotetext{
${ }^{2}$ By raising the price of imports relative to domestic goods devaluations create an expansionary substitution effect but this is outweighed by contractionary income effects, especially in the short-term (Agenor and Montiel 1996); devaluations reduce real wealth held in the local currency and more critically, shift income from wage earners who are likely to spend it to profit recipients who are not. Stein and Streb $(1998,1999)$ find a similar outcome within the context of a rational political business cycle model ( $a$ la Rogoff 1990), in which devaluations, understood as a tax on money balances, are delayed until after elections. Theory aside, empirical work shows that devaluations occur most frequently early in a term and very rarely shortly before elections (Edwards 1993; Frieden, Ghezzi, and Stein 2000).

${ }^{3}$ Export credits, insurance, and financing as well as trade agreements can all boost long-term export growth but are all too unwieldy to ensure export expansion prior to impending elections.
} 
international economic fluctuations might cause election timing. ${ }^{5}$ Of course, national differences in international economic exposure, institutions, and political circumstances, imply an upper bound on election clustering, but greater synchronization, demonstrated later in this paper, nevertheless provides circumstantial support for the international genesis of some elections and implies consequences for international politics.

Foremost among these consequences is the possibility of international cycles of conflict and cooperation. If governments are less amenable to international compromise preceding elections but more so afterwards, greater election synchronicity may create windows of opportunity for international agreements when multiple states are safely removed from election concerns as well as periods of intransigence prior to elections in which multiple states prioritize domestic interests (cf. Putnam and Bayne 1988). The abundance of endogenous timing states in Europe raises especially strong implications for the negotiation of European Union reforms and policy.

The remainder of this paper proceeds as follows. The following section examines the institutional and political prerequisites for what I term premier timing - i.e. the ability of the government to set its own election date - and identifies a sample of thirteen OECD countries. Note that premier timing countries are a distinct subset of endogenous timing countries, the better known category in which election dates are politically determined, regardless of means. In Section Two, with the aid of Cox hazard estimation, I then test whether exports affect election timing. As expected, the influence of export expansion on election timing rises over the parliamentary term. Section Three presents evidence of

\footnotetext{
4 "With the synchronization of electoral calendars in large capitalist democracies, we have a recipe for an international boom and bust cycle". Edward Tufte, 1978, p.69.

${ }^{5}$ Ito finds a surprising positive association between elections in the United States and economic growth in Japan.
} 
important secondary effects: (a) that, all things equal, the number of elections among premier-timing countries rises with their mean export growth and (b) that election cycle correlation has risen among the most economically integrated states, those of Western Europe. Section Four then discusses implications and concludes.

\section{Premier Timing}

Not all governments are able to call their own elections. Both constitutional provisions and political norms constrain political behavior, allowing opportunistic election calling in some states but preventing it in others. I construct the sample for this study by selecting the subset of the twenty-four member states of the Organization for Economic Cooperation and Development (OECD) in 1990 that possess the institutional arrangements necessary for opportunistic election calling. The OECD is a natural universe of cases with which to work because it includes the most highly integrated industrialized economies that conveniently also collect a similarly defined array of economic data. The fact that this group also includes most of the major military powers and economies also magnifies the importance of possible election clustering for international relations. Excluding countries that do not permit incumbents to set election dates pares the sample down to the thirteen countries identified in Table 2.1. ${ }^{6}$

This sample constraint, that incumbents must be able to time their own elections, requires greater explanation. The most obvious implication is the elimination of countries with fixed election-dates; this effectively censors all presidential systems

\footnotetext{
${ }^{6}$ Three OECD members - Greece, Spain, and Turkey - allow strategic election timing but have imperfect democratic records. Stable democracy in Greece and Spain since the mid-seventies
} 
(United States and Switzerland) and non-presidential systems with fixed election dates (Norway and Sweden). I exclude Sweden, a parliamentary democracy that allows early dissolution of parliament, because any parliament chosen by early elections can only serve out the remainder of the previous body's term. This is such a disincentive to early elections that none have been called since the implementation of the 1975 constitution.

\section{[TABLE ONE ABOUT HERE]}

Previous studies have termed elections held at legally required fixed intervals exogenous elections in order to distinguish them from endogenous elections, those whose dates are at least partly determined by domestic political processes. As this definition suggests, considerable variation exists among endogenous timing countries. Countries in which early elections require a failed vote of confidence - such as Germany - or are subject to approval by a politically relevant head of state - such as Belgium - are combined in the same category with countries where prime ministers can call snap elections on a whim - such as the United Kingdom.

I therefore propose a further typological refinement: premier v. non-premier timing. Premier timing requires that the incumbent executive have the de jure and de facto ability to initiate dissolution and early elections either directly or through a parliamentary majority whereas the non-premier category includes countries in which early elections are limited to extraordinary circumstances or election dates are set by any actor other than the government. Power over dissolution is held by the head of state in

allows their inclusion. Full military rule from 1980-83 and the continuing influence of the military in government disallows Turkey. 
many parliamentary democracies but where the president, governor-general, or monarch's role is primarily ceremonial - as is often the case - I have coded the country as premier timing. An excellent contrast in the roles of the head of state can be made between the United Kingdom, where the monarch has had only a ceremonial role in parliamentary dissolution, and Belgium, where the politically empowered monarch rejected a government's resignation as recently as $1985 .^{7}$ Thus, the United Kingdom is included and Belgium is not.

In limiting the sample to premier timing countries, I also remove all countries in which dissolution can only occur in extraordinary circumstances such as following a vote of no confidence or constitutional amendment. Germany has perhaps the most unusual system: dissolution may only follow the defeat of a vote of confidence introduced by the chancellor, i.e. the government must engineer its own defeat in order to call early elections. While this arrangement technically leaves the ability to time elections strategically within the chancellor's grasp, the extremely odd scenario of the governing coalition publicly voting en masse against confidence in itself is generally sufficient to prevent such an event from occurring. ${ }^{8}$

\footnotetext{
${ }^{7}$ King Baudouin refused Premier Wilfried Martens' bid for governmental resignation after a Cabinet session failed to resolve a split in his Christian Democrat-Liberal coalition. The monarchy continues to matter in Belgian politics. Belgium is additionally excluded because of recent coordination with Luxembourg to hold elections concurrently with those for the European Parliament.

${ }^{8}$ Early elections actually occurred twice in post-war Germany. Helmut Kohl engineered exactly such a failed vote of confidence in himself on December 17, 1982 and invoked Article 68 of the German Grundgesetz to dissolve parliament and call early elections. This followed unique circumstances, however, and is unlikely to be repeated. Kohl had recently come to power via a constructive vote of no confidence and sought a popular mandate. The main opposition (SPD) believed that voter disapproval of such political maneuvering would benefit them and thus did not oppose early elections. The Federal Constitutional Court later found this use of the vote of confidence legal but restricted its use. The non-partisan Federal president could also have refused the request for dissolution but did not because of opposition support. A later attempt by Kohl to move up Federal elections by seven weeks in the fall of 1990 to capitalize on reunification
} 
One final and more complicated subset of countries remains to be considered:

Semi-presidential systems. Duverger (1980) first identified semi-presidential systems

as governments where the president is popularly elected and holds considerable powers

while a premier and cabinet, subject to parliamentary confidence, perform executive functions. ${ }^{9}$ The hybrid nature of semi-presidential systems thus allows them to be either premier or non-premier timing countries depending on whether rival or cooperative parties hold the two top offices and the division of power between the president and prime minister. Single party control of both the presidency and premiership could allow for collusion over election timing even when the power of dissolution may not formally originate with the premier; similarly, cohabitation by rival parties precludes favorable election timing and may even allow inopportune timing. Five of the remaining sample countries are semi-presidential - Austria, Finland, France, Iceland, and Portugal; I classify those countries that behave like parliamentary democracies with a weak president as premier timing. ${ }^{10,11}$

euphoria was opposed by the SPD and failed. An early election also occurred in 1972 after the SPD/FDP Bundestag majority eroded. Chancellor Brandt, with agreement from the CDU/CSU and President Heinemann, called a vote of confidence knowing in advance that the opposition would be able to defeat it. It is important to note that both early elections could not have occurred without the cooperation of both the opposition and the federal president.

${ }^{9}$ Shugart and Carey (1992: 23) later term such systems as premier-presidential.

${ }^{10}$ Duverger also identified Ireland as semi-presidential, a classification that I reject on the grounds advanced by Shugart and Carey: the Irish president has no constitutional powers and exerts no political influence. (Shugart and Carey, 1992: 71)

${ }^{11}$ I include Austria because its president fails to exercise political influence despite constitutional powers. The primary function of the Austrian president is to name prime ministers but this power has been largely useless in a system that has produced grand coalitions for much of the postwar period. The long-standing domination of Austrian politics by the ÖVP/SPÖ duopoly further eroded this power (Shugart and Carey, 1992) and probably will again after the recent implosion of the Freiheit party. Somewhat ambiguously, the Austrian constitution provides the premier with the power to dissolve parliament after "consultation" with parliament.

Finland is a president dominant system in which the president has reserve powers over foreign policy and government formation. The large number of small parties competing in Finland's fragmented political landscape further enhances the president's powers. The abundance 


\section{Exports and Elections}

Having identified the appropriate sample, I now consider how best to test for international economic influences on election timing. Interest rates are an intuitively appealing means of measuring the transmission of international economic influences. The international co-movements in national discount rates generated by capital mobility and formal exchange rate arrangements during much of the sample period suggest a role for a regional exchange rate arrangements such as the European Monetary System's rate mechanism in production election clustering. ${ }^{12}$ To the same degree that interest rate comovements support an international business cycle they may also create synchronized incentives for strategic election timing.

Rate movements are nevertheless problematic for measuring cross-border effects on election timing: changes in domestic interest rates do not capture cross-border influences; changes in other countries' rates are causally distant from domestic reactions

of small parties provide her with the de facto ability to include or exclude most parties from government almost regardless of election results - Kekkonen excluded the Finnish Conservative party from every coalition he named after 1966 - and precludes the need for early elections. Frequent cabinet crises and government resignations also rarely leave the premier in a position to consider election timing. Thus, Finland is excluded.

In Iceland, like Austria, the president is surprisingly acquiescent to the prime minister and parliament. This weakness is also reflected in the fact that no partisan candidate has ever sought the office. Arend Lijphart (1984:189) attributes this to the unusual ease by which the constitution can be amended - by a pure majority rule within parliament. An assertive president is likely to have his formal powers curtailed if she were ever to try to use them. Thus Iceland functions quite similarly to the Danish constitutional monarchy on which its post independence constitution is modeled and is included in the sample.

The strength and independence of the presidency in France and Portugal disqualifies them from inclusion.

${ }^{12}$ The imposition of narrow bands of allowable exchange rate fluctuation among participating currencies in the European Exchange Rate Mechanism (ERM) in 1979 (2.25 percent; 6 percent for Italy) also tied European interest rates more closely together than normal pressures of capital mobility and investment would dictate. As a result, interest rates of ERM members (Belgium, Denmark, France, Germany, Ireland, Italy, Luxembourg, and the Netherlands) co-varied, 
and subject to questions of which countries' rates to use. Equally as problematic, interest rate hikes are a lagging indicator of economic expansion, most often increasing after periods of election-inviting growth. Demanding that cause precede effect leaves only rate reductions as an, albeit long-lead, source of election opportunism. Rate cuts, however, most often indicate a weakening economy in need of several reductions before economic activity again accelerates. Although interest rate co-movements almost certainly undergird the international transmission of business cycles, no clear and reasonably immediate causal path exists to measure their effect on election calling.

Trade, on the other hand - or more precisely, exports - is more promising. As exports are by national income accounting identity a component of GDP,${ }^{13}$ they provide a direct and immediate measure of cross border influence on domestic output. Exports also have the virtue of being resistant to reverse causation. Short of devaluing the national currency, it is unlikely that incumbent governments could influence foreign demand for imports before elections. Currency devaluation, however, diminishes living standards and raises inflation - a dubious fillip to reelection prospects - and, given price stickiness, is unlikely to expand exports quickly enough to induce suspicion of reverse causation in quarterly data. Accordingly, I employ change in quarterly exports (Aexports) as the key predictor in this analysis.

encouraging simultaneous economic expansions or slowdowns among members and even some closely tied non-members.

${ }^{13} \mathrm{GDP} \equiv \mathrm{C}+\mathrm{I}+\mathrm{G}+\mathrm{NX}$ defines gross domestic product as the sum of consumption (C), investment (I), government spending $(\mathrm{G})$ and net exports $(\mathrm{NX})$. Expressing net exports explicitly and representing exports with EX and imports with IM produces GDP $=\mathrm{C}+\mathrm{I}+\mathrm{G}+\mathrm{EX}-\mathrm{IM}$; Imports, however, are composed of domestic consumption of foreign goods and services $\left(\mathrm{C}_{\mathrm{f}}\right)$, investment $\left(\mathrm{I}_{\mathrm{f}}\right)$, and government spending $\left(\mathrm{G}_{\mathrm{f}}\right)$ so that GDP $=\mathrm{C}+\mathrm{I}+\mathrm{G}+\mathrm{EX}-\left(\mathrm{C}_{\mathrm{f}}+\mathrm{I}_{\mathrm{f}}+\mathrm{G}_{\mathrm{f}}\right)$ which, with some rearranging, becomes GDP $=\left(\mathrm{C}-\mathrm{C}_{\mathrm{f}}\right)+\left(\mathrm{I}-\mathrm{I}_{\mathrm{f}}\right)+$ $\left(\mathrm{G}-\mathrm{G}_{\mathrm{f}}\right)+\mathrm{EX}$; Understanding domestic demand, noted with the subscript $\mathrm{d}$, as the difference of total and foreign demand then yields GDP $=\mathrm{C}_{\mathrm{d}}+\mathrm{I}_{\mathrm{d}}+\mathrm{G}_{\mathrm{d}}+\mathrm{EX}$ which I reexpress as GDP $=\mathrm{GDP}_{\mathrm{d}}+\mathrm{EX}$. Thus gross domestic product is readily decomposed into domestic $\left(\mathrm{GDP}_{\mathrm{d}}\right)$ and foreign $(\mathrm{EX})$ demand for domestically produced goods and services 
Also consider how exports can spread business cycles and elections under this trade mechanism. Economic expansion in a given country increases imports from trade partners, transmitting booms and election calling incentives from one state to another. Large booms or anticipated downturns, often the observational equivalent, therefore provide an incentive for multiple governments to call elections before the opportunity sours. Naturally, as a government's remaining term wanes the threshold for what constitutes a sufficient election calling incentive diminishes together with the remaining calling opportunities and term time that would be surrendered by dissolution. Governments, therefore, wish to call elections in the last best period possible.

\section{Hazard Analysis}

Election timing can be modeled with multiple methods. In the analysis below, I choose Cox hazard estimation for its ease in right censoring non-opportunistic elections without biasing estimation and its ability to accommodate time-varying covariates with partial likelihood estimation. ${ }^{14,15}$ I estimate the hazard of elections in two identical progressions of model specifications, each with a different dependent variable (i.e., failure event). The first series of models, presented in Table Two, considers all early elections; the second series of models, presented in Table Three, employs only those

\footnotetext{
${ }^{14}$ Discrete-time logit, as we should expect (Beck, Tucker, and Katz 1998), yields nearly identical results.

${ }^{15}$ Cox hazard models can more easily accommodate time-varying covariates than can fully parametric proportional hazard models because they require no distributional assumptions about the underlying baseline hazard. The genius of Cox models is that no such modeling assumption is necessary. In its simplest form, excluding time-varying covariates, Cox models estimate hazard as $\mathrm{h}(\mathrm{t})=$ $\lambda_{0}(\mathrm{t}) e^{\beta_{1 \times 1}+\ldots+\beta_{\mathrm{k} \times \mathrm{k}}}$ where $\lambda_{0}$ is the baseline hazard. Thus the natural log of the hazard is just the log of the baseline hazard, call this $\gamma(\mathrm{t})$, plus $\beta X$. Now if $\gamma(\mathrm{t})=\gamma$ we have reproduced the exponential model; $\gamma(\mathrm{t})=\gamma \mathrm{t}$, the Gompertz model; and $\gamma(\mathrm{t})=\gamma \log \mathrm{t}$, the Weibull model. This is why Cox models require no a priori assumptions about the form of the baseline hazard.
} 
early elections that I have coded as opportunistic. Early elections comprise all elections that do not fall in the final quarter of a parliament's maximum constitutional tenure. As final quarter elections are induced by constitutional maximum term provisions they are clearly not opportunistic. Opportunistic elections, as coded here, include all early elections that were not induced (a) by votes of no confidence, (b) by coalition splits, or (c) by the failure of minority governments to win investiture or sufficient outside support to govern. The data appendix more fully explains the coding. Reconstructing the motives of governments for calling elections is a difficult process that inevitably introduces measurement error, so I employ both objectively coded early elections and subjectively coded opportunistic elections in parallel analyses.

Both analyses, except where explicitly noted, employ quarterly economic and political data from all thirteen OECD premier timing countries covering the period from 1967:1 - the start date for several IMF economic time series - to 1998:4. 1967 is an appropriate initial observation date because it allows ample time for any possible synchronization from the initial wave of post-war elections to dissipate. All models treat parliaments, defined as the periods between elections regardless of coalition composition, as subjects and use one of the two failure events. I circumvent concerns about left truncation by including only those governments that began in or after the first quarter of the 1967:1 to $1998: 4$ observation window. One single-quarter parliament as well as nondemocratic periods in Greece and Spain are omitted, leaving 124 parliaments with 90 early election and 60 opportunistic election failure events. Of course, different countries in the sample have (a) different maximum term lengths (CIEP) that could bias hazard estimates and (b) country-specific variances in election timing beyond those explained by 
the model that could introduce heteroskedasticity. I therefore stratify all models by CIEP ${ }^{16}$ and cluster robust standard errors on country. Finally, ties are resolved via the Breslow method. ${ }^{17}$

Table Two presents the hazard coefficients and robust standard errors for five models using the first failure event, early elections. The analysis proceeds as follows: I begin with the most parsimonious reasonable specification testing for the effect of percentage changes in exports, interacted with time in office, on the hazard of elections; I then progressively add variables to address rival explanations and potential sources of omitted variable bias. If incumbents maximize both time in office and the probability of re-election, calling an election in the last best period possible, then an interaction of time and $\Delta$ exports is the theoretically appropriate model. The risk of an increase in exports inducing elections should increase as a government's remaining term wanes.

\section{[TABLE TWO ABOUT HERE]}

The base specification in Model 2.1 quickly disposes of the null hypothesis about trade: The interaction of the (seasonally adjusted) percentage growth in exports with the number of quarters since the last election is positive and significant. The effect that an increase in exports has on the hazard of an election occurring increases as a parliamentary term matures. Export expansions are initially negatively associated with election hazard when time in office equals zero but in the tenth quarter in office, export expansions begin

\footnotetext{
${ }^{16}$ Stratifying the sample in a Cox model, as I do, is equivalent to running separate regressions with the constraint that the coefficients remain equal. Differences between strata are thus attributed to the respective underlying baseline hazards.

${ }^{17}$ The Breslow method implicitly assumes that that ties really occur at discrete time and has consequently been found to bias coefficient estimates slightly downward (Allison 1995). Ties are not sufficiently common in the present data for this to constitute a major concern. Moreover,
} 
to increase the hazard of an early election. This roughly matches the conventional wisdom about early elections: Parliamentary dissolutions early in a term are often due to weak governments and poor circumstances; those governments strong enough to survive the initial period then wait until the second half of a term to look for an opportunity to call elections in a period of strength. Although these results are encouraging, the absence of obvious control variables warrants caution.

The first controls are economic: percentage growth in gross domestic product (GDP) and the export dependence of a country (exports/GDP). Intuitively, growth in GDP should have a similar effect to that of exports, albeit lagged as domestic commerce is recorded at the transaction time rather than when the goods cross a border. ${ }^{18}$ As we are interested in the effect of export shocks in election calling, it is necessary to control for shocks to growth originating elsewhere. The second economic control, export exposure, the proportion of national income derived from foreign demand, is a necessary control for countries' expected responsiveness to export shocks. Export shocks probably have greater effect on the overall economy in highly export dependent countries than in relatively more autarchic neighbors and consequently offer a stronger stimulus for opportunistic elections.

the expectation of a slight downward bias should only strengthen confidence in significant findings.

${ }^{18}$ As discussed in the System of National Accounts (UN, 1968, § 6.131-6.135, revised 1982) and IFS ( $\$ 7$, introduction to monthly volume) data descriptions, Balance of Payment export data is taken from customs sources which record transactions as they cross a border. This represents a substantial lag relative to domestic demand data which is recorded at the time of transaction when ownership changes hands. National Account export figures would circumvent this time inconsistency but would entail losing nearly $40 \%$ of the quarterly observations in the panel. Customs based trade data is more complete as missing export data can be inferred from the import data of trade partners, as is often done with IMF Direction of Trade Statistics (DOTS) data. 
As expected, when interacted with parliamentary time-in-office in Model 2.2, growth in lagged GDP significantly increases the early election hazard. GDP booms are associated with a significant increase in the hazard of early elections in the latter part of a term. ${ }^{19}$ Similarly reassuring, as GDP obviously exceeds the value of exports, the coefficient for the GDP interaction is larger. The inclusion of GDP growth, in fact, slightly increases the strength of the export interaction. Inclusion of export exposure (exports/GDP), which remains insignificant, also does not lessen the time-mediated effect or significance of export shocks. In short, the effect of export expansion on the risk of early elections is robust to GDP growth and export exposure controls.

\section{[FIGURE ONE ABOUT HERE]}

The overall relationship between export expansion, time since the last election, and early election hazard is best demonstrated graphically. Figure One plots the election hazard predicted by coefficients and baseline hazard nearly identical to those in Model 2.2 for a hypothetical country with all covariates other than change in exports set at their sample means. I actually use the coefficients and baseline hazard from the more fully specified Model 2.4, but the interpretation is identical. ${ }^{20}$ The steep rise in the predicted election hazard in the figure's upper right-hand corner preceded by an exceptionally flat relationship highlights the effect of time and trade. Export expansion raises election hazard in approximately the final half of an incumbent's term but has no effect prior to that. As mandatory elections approach, however, this model predicts a strong positive

\footnotetext{
${ }^{19}$ An open question is what role electorally motivated economic manipulation may play. Unlike foreign demand (i.e., exports), which is largely insulated from pre-election manipulation, domestic demand is susceptible to government macroeconomic influence.

${ }^{20}$ As Cox hazard models do not assume a functional form hazard, I extract a baseline hazards at each quarter from model 2.4, plot it with coefficient effects, and assemble them into Figure One.
} 
effect for export expansion on the risk of elections. Conversely, holding the hazard of an early election fixed, the export growth threshold for any given hazard of early elections diminishes as a term matures. Given an expiring term and imminent mandatory polls, most governments will accept even modest economic improvement as an impetus for calling elections. Thus, a one standard deviation increase in export growth above its mean - i.e., an increase in export growth from 2.8 to 11.3 percent - corresponds to only a 4.3 percent increase in the risk of an early election when a parliament still has half its term to run (quarter 10), but a 34.4 percent increase in a more mature parliament (quarter 15), and a 56.5 percent increase in an aged parliament (quarter 18). ${ }^{21}$ Exceptional booms, obviously, have even larger effects.

Election timing is also an inherently political act that should respond to political events. Model 2.3 adds two theoretically relevant political determinants of election calling to the previous model. The first, newleader is a dummy that indicates a change of prime minister in the current or previous two quarters. New leaders seeking legislative influence can benefit from a popular mandate derived from elections. The temptation to turn to elections should also be greater for leaders who come to power relatively late in a parliamentary term when a smaller remainder of the present term is risked via elections. Thus I also interact newleader with time elapsed. The second political covariate is scandal, the subjectively coded political importance of scandals $(3=$ major abuse of office involving major government or governing party figures; 2 = minor abuse by a major figure or major abuse by a minor figure; 1 = minor abuse by a minor figure). I depreciate scandals by one unit each quarter so a large scandal, for example, can influence election calling for three quarters. When multiple scandals occur in proximity

${ }^{21} \Delta \mathrm{h}=\left[\mathrm{e}^{(.006 t \delta-.055 \delta)}-1\right] 100$ 
to one another, I aggregate their scores. Scandal, surprisingly, has no significant effect on the hazard of early elections but I suspect substantial measurement error. The presence of a new leader, in contrast, substantially and significantly increases early election hazard as a term progresses. The effect of exports remain remains robust to these political controls.

An additional source of bias in the estimated effect of exports could be the absence of controls for seasonal effects independent of economic output. A disproportionate number of early elections fall in the second (32) and fourth (36) quarters relative to the first (17) and third (12). ${ }^{22}$ If second and fourth quarters also enjoy above average export growth - despite that fact that export data are seasonally adjusted Aexports could be biased upwards. This, in fact, does not occur: Adding quarter dummies in Model 2.4 actually raises the export interaction coefficient, albeit only in the fourth decimal place. The GDP interaction and all other covariates save newleader also remain largely unchanged. The coefficient of the newleader interaction increases by approximately 25 percent when controlling for quarter possibly suggesting that voters and hence new leaders - discount expected seasonal booms. ${ }^{23}$ Most importantly, however, late-term export growth remains a persistently robust predictor of elections.

As an additional test, I replicate Model 2.3 on a subsample of 80 European parliaments. $^{24}$ The European countries - which exclude the two OECD premier timing countries with three year CIEPs, Australia and New Zealand - have, on average, longer

\footnotetext{
${ }^{22}$ The seven additional early elections here are from parliaments that began before the observation window (six) or from one-quarter parliaments censored from the risk set (one).

${ }^{23}$ This would be consistent with Palmer and Whitten, 1999.
} 
maximum term lengths which increase their risk of calling early elections (cf. Kayser 2005); they also trade more as a proportion of GDP and experience greater export volatility, two features that provide larger incentives for opportunistic election calling. We therefore should expect exports to induce a greater risk of early elections within Europe. They do: Export shocks in European countries are associated with a higher risk of early elections as a parliament matures than in the full sample.

We have seen from the above that export expansions are robustly associated with a rising hazard of early elections as parliaments mature. Early elections, however, do not necessarily constitute opportunistic elections. Early elections often can and do occur for non-opportunistic reasons such as votes of no confidence or coalition splits - phenomena that should, ideally, be employed in defining a more precise failure event. With the aid of newspaper reports and other records (see details in data appendix) I construct precisely such a variable - opportunistic elections - that indicates the subset of early elections that were not induced by votes of no confidence, coalition splits, or the failure of minority governments to win outside support. Identifying the true intention of a premier in dissolving parliament for elections is, of course, inevitably subjective. A prime minister, for example, might anticipate a coalition crisis and prefer to call an early election despite unfavorable external conditions. Such an election would nevertheless be coded as opportunistic. Despite these concerns, however, this relatively subjective measure may encompass less - or at least different - measurement error than the more objective early election failure event employed above.

\footnotetext{
${ }^{24}$ More specifically, I include all parliaments from the nine European premier timing states - Austria, Denmark, Greece (post 1974:4), Iceland, Ireland, Italy, the Netherlands, Spain (post1979:1), and the UK that began after January 1 of 1967.
} 


\section{[TABLE THREE ABOUT HERE]}

Table Three replicates the five model specifications from Table Two with opportunistic rather than early elections as the failure event. Restricting the set of elections from the previous analyses reduces the number of opportunistic elections from 90 to 60 in the general sample and from 56 to 32 in Europe. Despite this substantial change in the failure coding, few differences emerge in the results: (a) the interaction of export changes with parliamentary time in office remains largely unchanged in the magnitude of its effect but now becomes uniformly significant at the one percent level across all five models; (b) aggregate growth roughly doubles its interaction strength, reaching a magnitude consistent with its size relative to exports; both GDP and its effect on election calling now exceed the their export counterparts by about a factor of four; and (c) the new leader dummy - which yielded a significant effect in two out of the three models in Table Two - no longer even approaches statistical significance under the new failure event, suggesting that the earlier result was probably the result of new minority governments that soon collapsed. No other noteworthy differences emerge, emphasizing the central finding of consistency; regardless of whether objective early elections or more subjectively coded opportunistic elections were employed, export expansions, like expansions in general, remain a robust predictor of election timing.

\section{Election Clustering}

National election processes have conventionally been considered a domestic matter. The results presented above, however, contest this view. Not only do domestic economic expansions increase the risk of elections at home but, as booming economies 
transmit their growth to neighboring states via trade, in trade partners as well. National elections in premier timing countries are partly induced by foreign economic fluctuations. If trade transmitted economic booms are indeed inviting opportunistic elections, we should expect several empirically testable ancillary relationships - most notably, international election clustering and a growing correlation of election cycles among the most economically integrated states. Both of these patterns emerge.

I test for the first expected relationship - concurrent elections - with a series of Poisson regressions predicting the number of elections that fall in a given quarter. More precisely, the models predict one of two dependent variables: (1) the number of early elections, i.e., those elections that do not fall in the final quarter of the maximum term and (2) the number of opportunistic elections, i.e. those elections that qualify as opportunistic using the same rules as above. The regressors are calculated as either sums (scandals, newleaders) or means ( $\triangle$ exports, $\Delta G D P_{t-1}$, exports $/ G D P$ ) of their country values with one exception: scandals simply sums the number of countries that have a scandal in the given quarter (not the magnitudes). Two new covariates also appear: elapsed, unnecessary in the earlier duration models, now records the average proportion of maximum terms that have passed and elections $_{t-1}$, is the lagged dependent variable (early elections for the first three models, opportunistic elections for the final three). The election count data, somewhat unusually, raise theoretical concerns about possible negative autocorrelation as well as heteroskedasticity. Negative autocorrelation could arise from the lower likelihood, shown in the previous hazard models, of governments calling elections at the beginning of a new parliament. A large number of elections in a given quarter could therefore reduce the number of elections in the subsequent quarter. 
The rather mild - and negative - autocorrelation, however, recommends against a Poisson autoregressive model (Brandt and Williams, 2001). Heterogeneity in election calling across countries suggests possible overdispersion of the data. Summary statistics reassure us, however, that the count means exceed their variances, albeit by a very slight margin. I therefore proceed with a common Poisson and mitigate the mild autocorrelation and heteroskedasticity problems by including a lagged dependent variable and clustering robust standard errors by year.

\section{[TABLE FOUR ABOUT HERE]}

Table Four suggests that export booms are indeed associated with election clustering. Mean export growth among the premier timing countries is positively and significantly associated with both the number of early and opportunistic elections. The most fully specified model for each dependent variable reports a significant effect for export growth robust to the inclusion of relevant covariates. The substantive effect is also not negligible. Considering Model 4.6, for example, a one standard deviation increase in exports beyond the mean growth - i.e. increasing export growth from 2.9 percent to 6.8 percent - increases the expected number of opportunistic elections by a factor of 1.23 , all else equal.

The lagged dependent variable is initially statistically insignificant but, contrary to initial expectations, becomes positive and significant in Models 4.3 and 4.6. An increase in the number of elections in a given quarter also increases the number of elections in the subsequent quarter. This suggests that elections may attract elections. Small countries might want to preempt an expected negative precedent for their voters by calling national elections before those of a larger rival. John Howard, for example is 
suspected of calling Australia's October 9, 2004 elections before those of the US to avoid cross-border anti-incumbent contagion should his Iraq War ally, George Bush lose in November 2004 (Economist, 4 Sept. 2004). Incumbent success in a given country might also encourage incumbents elsewhere. This effect probably exceeds that of the negative autocorrelation because the election clusters remain fairly modest in magnitude.

GDP growth, unsurprisingly, also proves a significant predictor of election count albeit only at the ten percent level of significance in Model 4.6. Export exposure (Exports/GDP) and scandals perform much better in predicting election clusters than election hazard. Greater export exposure increases election clustering but scandals decrease the expected number of elections. The number of new leaders has no significant effect on the number of elections, early or opportunistic, but the autumn (fourth quarter) proves a popular time.

These findings have strong and novel implications for international political economy. The election clustering noted by Tufte may actually be a result of internationally transmitted business cycles rather than the converse as previously assumed.

\section{Convergence?}

Of course, if internationally transmitted expansions invite election clustering we should also expect an effect over time. Even a mild effect of trade on election clustering should reflect the increase in international trade and economic integration over that last decades. Business cycle convergence should, in short, imply election cycle convergence. Of course, different CIEPs and country-particular events imply an upper bound on 
election cycle convergence but the rise in economic interdependence and the emergence of international business cycles nevertheless imply a waxing impetus toward election clustering. Have elections become more synchronized? Nowhere should this trend be stronger than in Europe where the European Union has steadily reduced trade barriers, stabilized exchange rates, lowered barriers to capital mobility, and generated an increasingly synchronized European business cycle. Indeed, as Artis and Zhang (1997 and 1999) show, European business cycles converged after the introduction of the European Monetary System's European rate mechanism (ERM) in 1979 through the mid 1990s.

To test this, I construct a vector of the number of days from July 1 to the next election for each of each year in each country and then correlate the vectors of each country dyad. Measuring from the middle of each year to the next election provides a common benchmark and an equal number of observations. This approach also offers the simplicity of an election analog to business cycle correlation while the standardization employed in the calculation of correlation coefficients facilitates comparison across different variances. Figure Two plots the twenty-year moving-average election-cycle correlation between six European countries ${ }^{25}$ and Austria, a small highly integrated European country. A few years after the introduction of the ERM, European election cycles - much like European business cycles - began converging with one another while

\footnotetext{
${ }^{25}$ Denmark, Iceland, Ireland, Italy, Netherlands, UK. This (including Austria) is the complete set of European states that have had democratic governments for the necessary time series length and are able to time their elections opportunistically. Thus, Spain and Greece are omitted. The value reported at each year represents the mean of six bivariate correlations between the European countries and Austria's cycle over the current and nineteen preceding years. The correlation mean with the US includes Austria as well.
} 
diverging from that of the United States. In short, as European business cycles converged, so did European election cycles.

\section{[FIGURE TWO ABOUT HERE]}

Of course, these results are more suggestive than conclusive. Interpreted in the context of the other results, however, they provide reason to suspect that economic trends have influenced clustering, especially in Europe where the necessary institutional and economic conditions are most common.

\section{Conclusion}

This paper introduces a novel claim about the effect of international economic integration on national politics, namely that international business cycles influence the timing of domestic elections. In doing so, it marshals evidence for several specific claims: (a) that governments time elections in response to economic fluctuations regardless of whether they originate domestically or abroad, (b) that incumbents maximize both their time in office and reelection probabilities, calling elections toward the end of their terms in economically advantageous periods, and (c) that as a term matures, governments become increasingly opportunistic, responding to smaller shocks that they would have foregone earlier in their term. External economic effects on national election timing also imply several secondary effects among premier timing countries, specifically: (d) that increases in exports increase the temporal clustering of elections and (e) that election cycles among European countries have become increasingly correlated over time. If premier timing governments are indeed as opportunistic in their timing of elections as these results suggest, then the distinction 
between endogenous timing (or more precisely, premier timing) and fixed timing states may be a far more important institutional dimension than previously thought.

Domestically, not only does premier timing matter for incumbency advantage and governance (credible dissolution threats may empower the government relative to the legislature), but also for the "electoral economy" of a state. Governments that are able to coordinate elections with exogenous opportunities may have less of an incentive to manipulate their economies prior to elections.

Internationally, the external economic effects on national election timing raises the prospect of election clustering among the most economically integrated states, most notably those of western Europe. Unlike the introduction of previous regional exchange rate (and given capital mobility, monetary) regimes, the recent implementation of European economic and monetary union has caused a much documented initial divergence in business cycles (cf. Economist, 2 Oct 2004). But divergence is expected to give way to renewed business cycle - and the is paper would add election cycle convergence in the long run. If states approaching elections behave differently from those removed from immediate reelection concerns, incumbents facing imminent polls should emphasize short-term domestic interests over cooperation with foreign governments. A growing synchronization of election calendars thus could imply international cycles of cooperation and conflict with elections preceded by discord and followed by détente.

By establishing that external economic cycles affect the timing of national elections, this paper raises questions about globalization's political consequences. Many scholars have already questioned the effect of freer flows of goods, services, and capital 
on the ability of governments to set domestic policy; none have examined the effect on the electoral process itself. Institutional variation may be the final mile in predicting globalization's effects in different countries. Election-calling institutions should not be neglected in this endeavor. 


\section{Appendix}

\section{Hazard Analysis Variables}

ElecErly - Early elections. Elections that do not fall in the final quarter of a parliament's maximum tenure. Those that are held in the final quarter of a maximum term are assumed to be induced constitutionally. Omits non-democratic years for Greece and Spain. Coded as failure event. Source: information on election dates from Mackie and Rose, The International Almanac of Electoral History and, for more recent elections, governmental websites and the International Parliamentary Union.

ElecOpp - Opportunistic elections. Elections that 1) do not fall in the final quarter of a parliament's maximum term and 2) were not induced by votes of no confidence, coalition splits, or the failure of minority governments to win investiture or sufficient outside support to govern. Omits non-democratic years for Greece and Spain. Coded as failure event. Source: information on the cause of elections taken from 1) The Annual Register of World Events, 2) Keesing's Contemporary Archives, and 3) various newspaper articles retrieved via Nexis-Lexis.

$\Delta$ exports - The percent change in exports, quarter to quarter, seasonally adjusted by author where no already done so by national data providing authorities. Source: International Monetary Fund (IMF) International Financial Statistics (IFS) data series and, where needed, IMF Direction of Trade Statistics data.

$\Delta \mathbf{G D P}_{\mathbf{t}-\mathbf{1}}-$ Percent change in gross domestic product, quarter to quarter, lagged one quarter. Source: IMF IFS quarterly data. Approximately one third of observation quarters are missing data in which case I impute quarterly data from annual GDP time series setting the first quarter figure equal to annual GDP/ $x$ where $x=r^{3}+4 r^{2}+6 r+4$ and $r$ is the mean quarterly GDP growth rate for the extant 1059 observations, 2.27 percent. All models have been run with an impute dummy to verify that these data do not affect results.

Exports/GDP - Exports divided by gross domestic product, all in US dollars converted at current exchange rates. Source: IMF IFS data.

New Leader - Dummy variable indicating a change of prime minister within the same parliament in the present or previous two preceding quarters. Source: Goemans, Gleditsch, Chiozza, and Choung (2004) leadership dataset.

Scandal - Variable indicating political scandal. Coding: 3) scandal involving major government or governing party member. Major abuse of power or neglect of responsibilities leading to severe consequences or potential consequences; 2) minor abuse by major government figure or major abuse by minor government figure; 1) minor abuse or failure by minor government figure. Scandals are discounted by one point each quarter and are cumulative. Sources: 1) Annual Register of World Events, 2) Political Scandals and Causes Celebres since 1945: An International Reference Compendium (1991), and 3) Lexis-Nexis.

Time - quarters since last election. 
Poisson Regression Variables ${ }^{26}$

ElecErly - The sum of early elections in the thirteen premier timing countries for the given quarter. Greece and Spain excluded from exposure count in non-democratic years. Early elections are those that do not fall in the final quarter of a parliament's maximum term.

ElecOpp - The sum of opportunistic elections in the thirteen premier timing countries for the given quarter. Greece and Spain excluded from exposure count during nondemocratic years. Opportunistic elections 1) do not fall in the final quarter of a parliament's maximum term and 2) were not induced by votes of no confidence, coalition splits, or the failure of minority governments to win investiture or sufficient outside support to govern.

Elapsed - Time since last election (TSLE) divided by the maximum constitutional interelection period (CIEP), i.e. the proportion of the maximum term that has elapsed.

Elapsed reports the mean for the thirteen premier timing countries.

Elections $_{\mathrm{t}-1}$ - the number of elections, of all types, in the previous quarter.

$\Delta$ exports - mean percent change in exports, quarter to quarter, seasonally adjusted.

$\Delta \mathbf{G D P} \mathbf{P}_{\mathbf{t}-\mathbf{1}}$ - mean percent change in gross domestic product, quarter to quarter, lagged.

Scandals - number of scandals. Sum of a scandal dummy.

New Leaders - number of countries with a new leader within a parliament in the current or two preceding quarters.

${ }^{26}$ see previous variable definition table for data sources. 


\section{References}

Agenor, Pierre-Richard and Peter Montiel. 1996. Development Macroeconomics. Princeton, NJ: Princeton University Press.

Allison, Paul D. 1995. Survival Analysis Using the SAS System. Cary, NC: SAS Institute.

Alesina, Alberto, Nouriel Roubini, Gerald Cohen. 1997. Political Cycles and the Macroeconomy. Cambridge, MA: MIT Press.

Artis, Michael J. and Wenda Zhang. 1997. "International Business Cycles and the ERM: Is There a European Business Cycle?" International Journal of Finance and Economics 2: 1-16.

Artis, Michael J. and Wenda Zhang. 1999. "Further Evidence on the International Business Cycle and the ERM: Is there a European Business Cycle?" Oxford Economic Papers 51: 120-132.

Balke, Nathan S. 1990. "The Rational Timing of Parliamentary Elections.” Public Choice 65: 201-216.

Beck, Nathaniel, Jonathan Katz, and Richard Tucker. 1998. "Taking Time Seriously: TimeSeries-Cross-Section Analysis with a Binary Dependent Variable." American Journal of Political Science 42(4):1260-88.

Brandt, Patrick T. and John T. Williams. 2001. “A Linear Poisson Autoregressive Model: The Poisson AR(p) Model.” Political Analysis 9(2, July):164-84.

Blais A, Gidengil E, Nevitte N, Nadeau R. 2004. "Do (Some) Canadian voters punish a prime minister for calling a snap election?" Political Studies 52 (2): 307-323.

Bordo, Michael D., Barry Eichengreen, and Douglas A. Irwin. 1999. Is Globalization Today Really Different from Globalization a Hundred Years Ago? In Brookings Trade Forum 1999. Susan M. Collins and Robert Z. Lawrence, eds. Washington: Brookings Institution.

Cargill, Thomas F., and Michael M. Hutchinson. 1991. "Political Business Cycles with Endogenous Election Timing: Evidence from Japan.” The Review of Economics and Statistics 73: 733-739.

Chowdhurry, Abdur R. 1993. "Political Surfing over Economic Waves: Parliamentary Election Timing in India." American Journal of Political Science 37: 1100-1118.

Diermeier, Daniel and Randolph T. Stevenson. 2000. Cabinet Terminations and Critical Events. American Political Science Review 94: 627-40.

Duverger, Maurice. 1980. "A New Political System Model: Semi-Presidential Government." European Journal of Political Research 8: 165-87.

Economist Magazine, 4 September 2004, "Australia Calls an Election: The Truth Game."

Economist Magazine, 2 October 2004, "Economic Focus: Growing Apart.” 
Edwards, Sebastian. 1994. The Political Economy of Inflation and Stabilization in Developing Countries. Economic Development and Cultural Change 42(2).

Frieden, Jeffry, Piero Ghezzi, and Ernesto Stein. 2000. Politics and Exchange Rates: A CrossCountry Approach to Latin America. Working Paper R-421. Washington, DC: Inter-American Development Bank, Research Department.

Goemans, Hein, Kristian Skrede Gleditsch, Giacomo Chiozzo, and Jinhee L. Choung. 2004. Archigos: A Database on Political Leaders. Typescript. University of Rochester and University of California, San Diego. Version 1.5. May 2004.

Inter-Parliamentary Union. 1976. Parliaments of the World: A Reference Compendium. DeGruyter: New York and Berlin.

Ito, Takatoshi and Jin Hyuk Park. 1988. "Political Business Cycles in the Parliamentary System." Economics Letters 27: 233-238.

Ito, Takatoshi. 1990. "The Timing of Elections and Political Business Cycles in Japan." Journal of Asian Economics 1: 135-156.

Ito, Takatoshi. 1991. "International Impacts on Domestic Political Economy: a Case of Japanese General Elections." Journal of International Money and Finance 10: S73-S89.

Kayser, Mark A. 2005. "Who Surfs, Who Manipulates? The Determinants of Opportunistic Election Timing and Electorally Motivated Economic Intervention." American Political Science Review 99(1).

Lijphart, Arend. 1984. Democracies: Patterns of Majoritarian and Consensus Government in Twenty-One Countries. Yale UP: New Haven, CT.

Lupia, Arthur, and Kaare Strom. 1995."Coalition Termination and the Strategic Timing of Elections." American Political Science Review 89: 648-65.

Mackie, Thomas T. and Richard Rose. 1991. The International Almanac of Electoral History, $3^{\text {rd }}$ ed. Congressional Quarterly, Inc.: Washington, DC.

Palmer, Harvey D. and Guy D. Whitten. 1999. "The Electoral Impact of Unexpected Inflation and Economic Growth.” British Journal of Political Science 29 (4): 623-39.

Palmer, Harvey D. and Guy D. Whitten. 2000. "Government Competence, Economic Performance and Endogenous Election Dates." Electoral Studies 19: 413-426.

Putnam, Robert D. and Nicholas Bayne. 1988. Hanging Together: Cooperation and Conflict in the Seven-Power Summits. Cambridge, MA: Harvard University Press.

Przeworski, Adam, Michael Alvarez, Jose Antonio Cheibub, and Fernando Limongi. Democracy and Development: Political Institutions and Material Well-Being in the World, 1950-90.

Cambridge: Cambridge UP.

Rogoff, Kenneth. 1990. "Equilibrium Political Budget Cycles." American Economic Review 80: 21-36. 
Roper, Steven D. and Christopher Andrews. 2002. "Timing an Election: The Impact on the Party in Government." American Review of Politics 23 (Winter): 305-18.

Shugart, Mathew S. and John M. Carey. 1992. Presidents and Assemblies: Constitutional Design and Electoral Dynamics. Cambridge UP: Cambridge, UK and New York, NY.

Smith, Alastair. 2003. "Election Timing in Majoritarian Parliaments." British Journal of Political Science 33(3): 397-418.

Stein, Ernesto and J.M. Streb. 1998. Political Stabilization Cycles in High Inflation. Journal of Development Economics 56: 159-80.

Stein, Ernesto and J.M. Streb. 1999. Elections and the Timing of Devaluations. Working Paper 396. Washington, DC: Inter-American Development Bank, Research Department.

Strom, Kaare and Stephen M. Swindle. 2002. Strategic Parliamentary Dissolution. American Political Science Review 96: 575-91.

Thompson, William R. and Gary Zuk. 1983. "American Elections and the International Electoral-Economic Cycle: A Test of the Tufte Hypothesis." American Journal of Political Science 27 (3): 464-84.

Tufte, Edward R. 1978. Political Control of the Economy. Princeton UP: Princeton, NJ.

Warwick, Paul. 1994. Government Survival in Parliamentary Democracies. New York: Cambridge University Press. 


\section{Table One: Thirteen Premier Timing Countries}

\begin{tabular}{lccrr}
\hline \multicolumn{1}{c}{ Country } & Symbol & $\begin{array}{c}\text { Max Term } \\
\text { (years) }\end{array}$ & \multicolumn{2}{c}{ Mean $\Delta$ export $^{27}$} \\
& & elec qtr & no elec \\
\hline Australia & Aul & 3 & 0.12 & 2.54 \\
Austria & Aut & 4 & 8.10 & 3.53 \\
Canada & Can & 5 & 7.49 & 2.90 \\
Denmark & Dnk & 4 & 3.06 & 2.29 \\
Greece & Gre & 4 & 3.34 & 3.94 \\
Iceland & Ice & 4 & 28.00 & 5.12 \\
Ireland & Ire & 5 & 4.60 & 4.42 \\
Italy & Ita & 5 & 4.51 & 3.62 \\
Japan & Jpn & 4 & 7.88 & 3.23 \\
Netherlands & Nth & 4 & -0.27 & 3.66 \\
New Zealand & Nzl & 3 & 1.14 & 2.89 \\
Spain & Spn & 4 & 16.16 & 4.33 \\
UK & Uk & 5 & 8.18 & 2.88 \\
\hline
\end{tabular}

Source: Parliaments of the World (IPU), The World Encyclopedia of Parliaments and Legislatures (WEPL), and constitutions on-line (http://uni-wuerzburg.de/law/)

${ }^{27}$ 1967Q1 to 1998Q4; percent change over previous quarter. 
Table Two: Early Elections and Exports

Cox Hazard Estimation

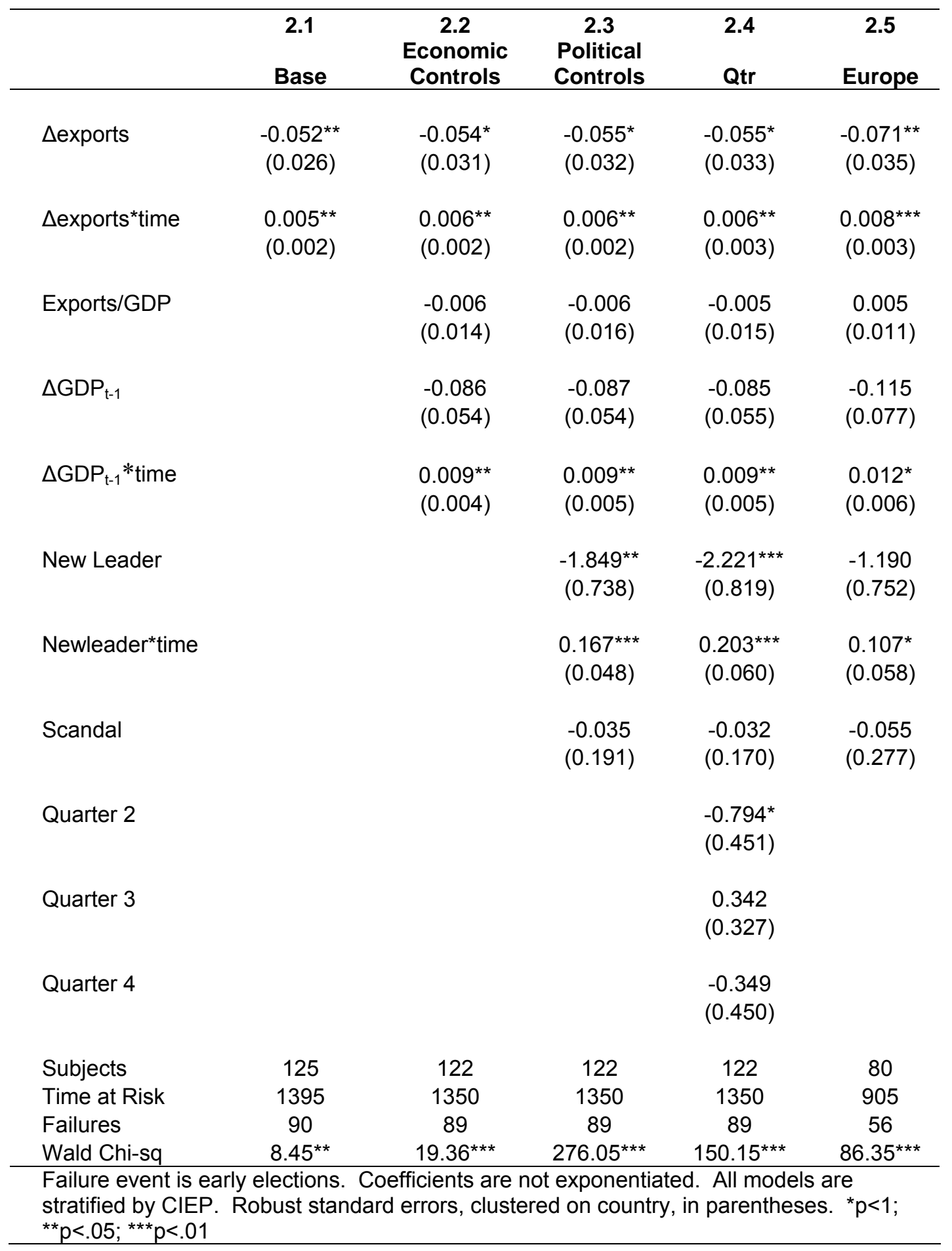


Table Three: Opportunistic Elections and Exports Cox Hazard Estimation

\begin{tabular}{|c|c|c|c|c|c|}
\hline & $\begin{array}{c}3.1 \\
\text { Base } \\
\end{array}$ & $\begin{array}{c}3.2 \\
\text { Economic } \\
\text { Controls }\end{array}$ & $\begin{array}{c}3.3 \\
\text { Political } \\
\text { Controls } \\
\end{array}$ & $\begin{array}{c}3.4 \\
\text { Quarter } \\
\text { Controls } \\
\end{array}$ & $\begin{array}{c}3.5 \\
\text { Europe }\end{array}$ \\
\hline$\Delta$ exports & $\begin{array}{c}-0.061^{* * *} \\
(0.022)\end{array}$ & $\begin{array}{c}-0.052^{* *} \\
(0.023)\end{array}$ & $\begin{array}{c}-0.053^{\star *} \\
(0.025)\end{array}$ & $\begin{array}{c}-0.054^{* *} \\
(0.024)\end{array}$ & $\begin{array}{c}-0.049^{\star *} \\
(0.022)\end{array}$ \\
\hline$\Delta$ exports*time & $\begin{array}{c}0.006^{* * *} \\
(0.002)\end{array}$ & $\begin{array}{c}0.005^{* * *} \\
(0.002)\end{array}$ & $\begin{array}{c}0.005^{* * *} \\
(0.002)\end{array}$ & $\begin{array}{c}0.005^{* * *} \\
(0.002)\end{array}$ & $\begin{array}{c}0.006^{* * *} \\
(0.001)\end{array}$ \\
\hline Exports/GDP & & $\begin{array}{l}-0.014 \\
(0.023)\end{array}$ & $\begin{array}{l}-0.015 \\
(0.026)\end{array}$ & $\begin{array}{l}-0.014 \\
(0.024)\end{array}$ & $\begin{array}{c}0.005 \\
(0.018)\end{array}$ \\
\hline$\Delta \mathrm{GDP}_{\mathrm{t}-1}$ & & $\begin{array}{l}-0.199^{*} \\
(0.114)\end{array}$ & $\begin{array}{l}-0.206^{*} \\
(0.118)\end{array}$ & $\begin{array}{l}-0.214^{*} \\
(0.112)\end{array}$ & $\begin{array}{l}-0.276 \\
(0.169)\end{array}$ \\
\hline$\Delta \mathrm{GDP}_{\mathrm{t}-1} *$ time & & $\begin{array}{l}0.018^{* *} \\
(0.009)\end{array}$ & $\begin{array}{l}0.018^{* *} \\
(0.009)\end{array}$ & $\begin{array}{l}0.019^{* *} \\
(0.008)\end{array}$ & $\begin{array}{l}0.024^{*} \\
(0.013)\end{array}$ \\
\hline New Leader & & & $\begin{array}{c}-0.71 \\
(1.056)\end{array}$ & $\begin{array}{l}-1.092 \\
(1.289)\end{array}$ & $\begin{array}{c}0.239 \\
(0.996)\end{array}$ \\
\hline Newleader*time & & & $\begin{array}{c}0.075 \\
(0.076)\end{array}$ & $\begin{array}{c}0.113 \\
(0.102)\end{array}$ & $\begin{array}{l}-0.046 \\
(0.087)\end{array}$ \\
\hline Scandal & & & $\begin{array}{l}-0.157 \\
(0.217)\end{array}$ & $\begin{array}{l}-0.142 \\
(0.209)\end{array}$ & $\begin{array}{l}-0.212 \\
(0.450)\end{array}$ \\
\hline Quarter 2 & & & & $\begin{array}{l}-0.971 \\
(0.641)\end{array}$ & \\
\hline Quarter 3 & & & & $\begin{array}{c}0.320 \\
(0.419)\end{array}$ & \\
\hline Quarter 4 & & & & $\begin{array}{l}-0.297 \\
(0.594)\end{array}$ & \\
\hline Subjects & 125 & 122 & 122 & 122 & 80 \\
\hline Time at Risk & 1395 & 1350 & 1350 & 1350 & 905 \\
\hline Failures & 60 & 59 & 59 & 59 & 32 \\
\hline Wald Chi-sq & $15.54^{* * *}$ & $32.14^{\star * \star}$ & $51.49^{* \star *}$ & $139.56^{* \star *}$ & $357.97^{\star * *}$ \\
\hline
\end{tabular}


Table Four: Poisson Regression

\begin{tabular}{|c|c|c|c|c|c|c|}
\hline & \multirow[t]{2}{*}{4.1} & \multirow{3}{*}{$\begin{array}{c}4.2 \\
\text { Early Election } \\
\text { Controls }\end{array}$} & \multirow[t]{2}{*}{4.3} & 4.4 & 4.5 & 4.6 \\
\hline & & & & \multicolumn{3}{|c|}{ Opportunistic Elections } \\
\hline & Base & & Quarters & Base & Controls & Quarters \\
\hline Constant & $\begin{array}{l}-2.269^{* * *} \\
{[0.696]}\end{array}$ & $\begin{array}{l}-4.725^{\star * *} \\
{[0.953]}\end{array}$ & $\begin{array}{l}-5.397^{\star * *} \\
{[1.044]}\end{array}$ & $\begin{array}{l}-3.514^{* * *} \\
{[0.764]}\end{array}$ & $\begin{array}{l}-6.250^{\star * *} \\
{[1.175]}\end{array}$ & $\begin{array}{l}-7.208^{* * *} \\
{[1.414]}\end{array}$ \\
\hline Elapsed & $\begin{array}{l}4.474^{* * *} \\
{[1.342]}\end{array}$ & $\begin{array}{l}5.870^{\star * *} \\
{[1.312]}\end{array}$ & $\begin{array}{l}6.311^{* * *} \\
{[1.227]}\end{array}$ & $\begin{array}{l}6.206^{* * *} \\
{[1.503]}\end{array}$ & $\begin{array}{l}7.962^{* * *} \\
{[1.560]}\end{array}$ & $\begin{array}{l}8.569^{* * *} \\
{[1.602]}\end{array}$ \\
\hline Elections $_{\mathrm{t}-1}$ & $\begin{array}{l}-0.082 \\
{[0.143]}\end{array}$ & $\begin{array}{l}0.001 \\
{[0.133]}\end{array}$ & $\begin{array}{l}0.229^{*} \\
{[0.131]}\end{array}$ & $\begin{array}{l}-0.029 \\
{[0.166]}\end{array}$ & $\begin{array}{l}0.058 \\
{[0.168]}\end{array}$ & $\begin{array}{l}0.361^{* *} \\
{[0.158]}\end{array}$ \\
\hline$\Delta$ exports & $\begin{array}{l}0.040^{* *} \\
{[0.018]}\end{array}$ & $\begin{array}{l}0.037^{*} \\
{[0.019]}\end{array}$ & $\begin{array}{l}0.037^{* *} \\
{[0.017]}\end{array}$ & $\begin{array}{l}0.051^{* *} \\
{[0.024]}\end{array}$ & $\begin{array}{l}0.050^{*} \\
{[0.027]}\end{array}$ & $\begin{array}{l}0.054^{* *} \\
{[0.026]}\end{array}$ \\
\hline$\Delta \mathrm{GDP}_{\mathrm{t}-1}$ & & $\begin{array}{l}0.105^{* * *} \\
{[0.037]}\end{array}$ & $\begin{array}{l}0.148^{* * *} \\
{[0.057]}\end{array}$ & & $\begin{array}{l}0.100^{* *} \\
{[0.044]}\end{array}$ & $\begin{array}{l}0.150^{*} \\
{[0.085]}\end{array}$ \\
\hline Exports/GDP & & $\begin{array}{l}0.069^{* *} \\
{[0.030]}\end{array}$ & $\begin{array}{l}0.064^{* *} \\
{[0.029]}\end{array}$ & & $\begin{array}{l}0.077^{* * *} \\
{[0.025]}\end{array}$ & $\begin{array}{l}0.073^{* *} \\
{[0.029]}\end{array}$ \\
\hline New Leaders & & $\begin{array}{l}0.057 \\
{[0.091]}\end{array}$ & $\begin{array}{l}0.067 \\
{[0.072]}\end{array}$ & & $\begin{array}{l}0.013 \\
{[0.086]}\end{array}$ & $\begin{array}{l}0.030 \\
{[0.061]}\end{array}$ \\
\hline Scandals & & $\begin{array}{l}-0.172^{* * *} \\
{[0.061]}\end{array}$ & $\begin{array}{l}-0.148^{* *} \\
{[0.061]}\end{array}$ & & $\begin{array}{l}-0.196^{* *} \\
{[0.093]}\end{array}$ & $\begin{array}{l}-0.174^{*} \\
{[0.100]}\end{array}$ \\
\hline Quarter 2 & & & $\begin{array}{l}0.147 \\
{[0.279]}\end{array}$ & & & $\begin{array}{l}0.223 \\
{[0.494]}\end{array}$ \\
\hline Quarter 3 & & & $\begin{array}{l}-0.330 \\
{[0.277]}\end{array}$ & & & $\begin{array}{l}-0.449 \\
{[0.459]}\end{array}$ \\
\hline Quarter 4 & & & $\begin{array}{l}0.786^{* * *} \\
{[0.272]}\end{array}$ & & & $\begin{array}{l}0.963^{\star * *} \\
{[0.328]}\end{array}$ \\
\hline Wald Chi-sq & $24.34^{\star * *}$ & $57.03^{* * *}$ & $65.67^{* * *}$ & $24.86^{* * *}$ & $60.99^{* * *}$ & $68.67^{* * *}$ \\
\hline $\mathrm{BIC}$ & $292.08^{* * *}$ & $299.14^{* * *}$ & $302.45^{* * *}$ & $240.97^{* * *}$ & $249.73^{* * *}$ & $253.01^{* * *}$ \\
\hline $\mathrm{N}$ & 127 & 126 & 126 & 127 & 126 & 126 \\
\hline
\end{tabular}


Table Five: Descriptive Statistics

Hazard Variables

\begin{tabular}{|c|c|c|c|c|c|}
\hline Variable | & Obs & Mean & std. Dev. & Min & $\operatorname{Max}$ \\
\hline sexports & 14 & -1 & ーーーーーーーー & -3 & 60528 \\
\hline $\begin{array}{c}\Delta \text { exports } \\
\text { Exports/GDP }\end{array}$ & $\begin{array}{l}1484 \\
1438\end{array}$ & $\begin{array}{l}2.839361 \\
22.83603\end{array}$ & $\begin{array}{l}8.451483 \\
11.41784\end{array}$ & $\begin{array}{r}-33.9 \\
7.87\end{array}$ & $\begin{array}{l}60.5^{20} \\
78.16\end{array}$ \\
\hline$\triangle \mathrm{GDP}$ & 1482 & 2.928462 & 4.546824 & -6.5 & $61 \cdot 18^{28}$ \\
\hline Newleader & 1488 & .0987903 & .2984806 & 0 & 1 \\
\hline Scandal | & 1488 & .1639785 & .5844829 & 0 & 6 \\
\hline
\end{tabular}

Poisson Variables

\begin{tabular}{|c|c|c|c|c|c|}
\hline Variable | & Obs & Mean & Std. Dev. & Min & Max \\
\hline Elecerly | & 128 & .7734375 & .8531077 & 0 & 4 \\
\hline Elecopp | & 128 & .53125 & .7202088 & 0 & 4 \\
\hline$\Delta$ exports I & 127 & 2.895103 & 3.867005 & -7.203077 & 12.50636 \\
\hline Exports/GDP | & 128 & 22.53773 & 2.534922 & 16.37667 & 29.79273 \\
\hline Elapsed | & 128 & .4203833 & .0785876 & .2192308 & .5892308 \\
\hline$\triangle \mathrm{GDP}$ & 126 & 2.931315 & 1.935255 & .3884615 & 9.341666 \\
\hline Scandals | & 128 & 1.132813 & 1.138939 & 0 & 5 \\
\hline Newleader | & 128 & 1.164063 & .9942935 & 0 & 4 \\
\hline
\end{tabular}

${ }^{28}$ Iceland has gone through huge cycles in fishing hauls and exports. Quarterly dummies and countryclustered robust standard errors should adjust for this. 
Figure One: Election Hazard, Time, and Exports

$$
\text { (Model 2.4) }
$$

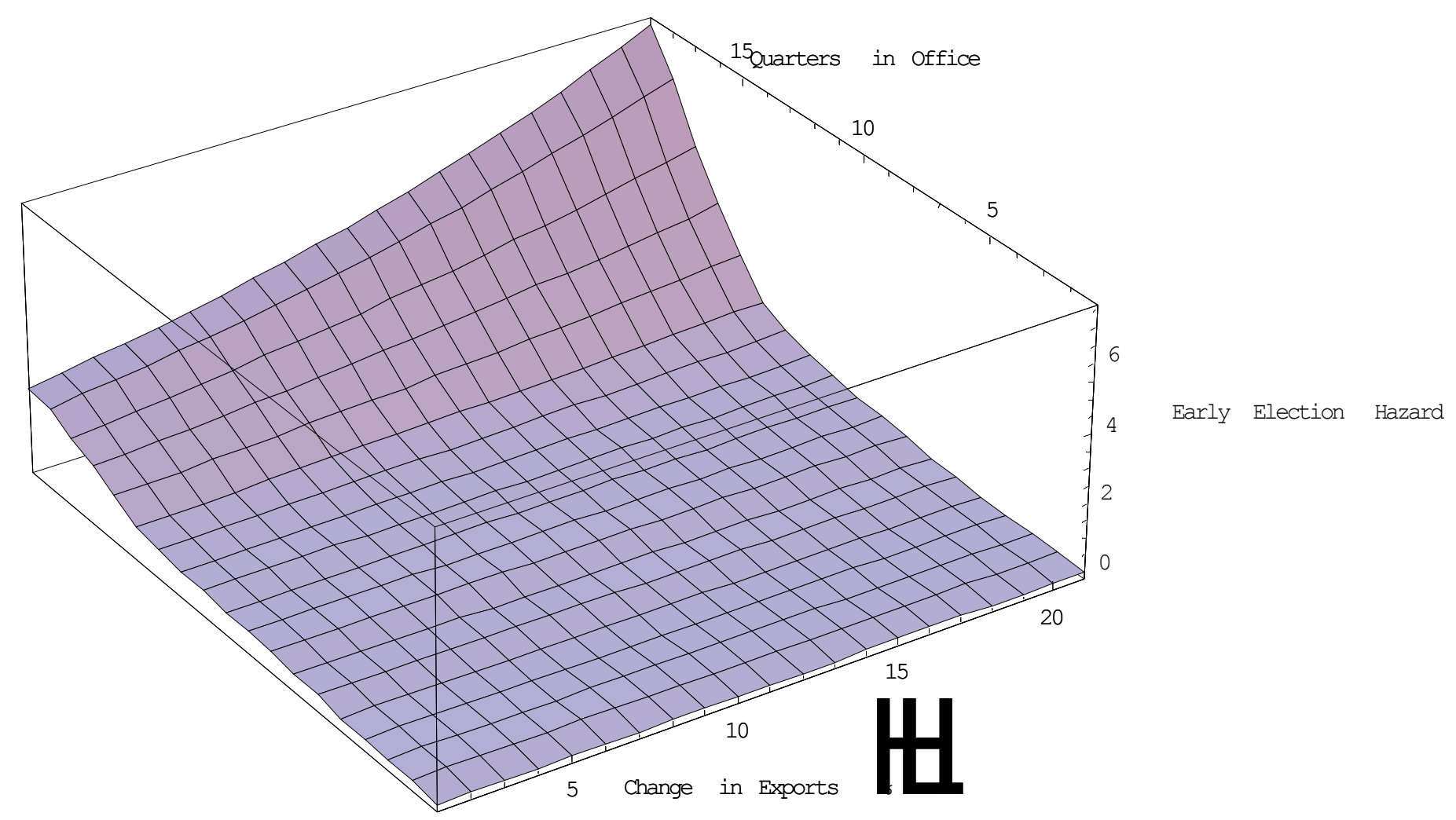


Figure Two: Election Cycle Convergence?

Mean Election Cycle Correlation of Seven European Countries with Given Country ${ }^{29}$

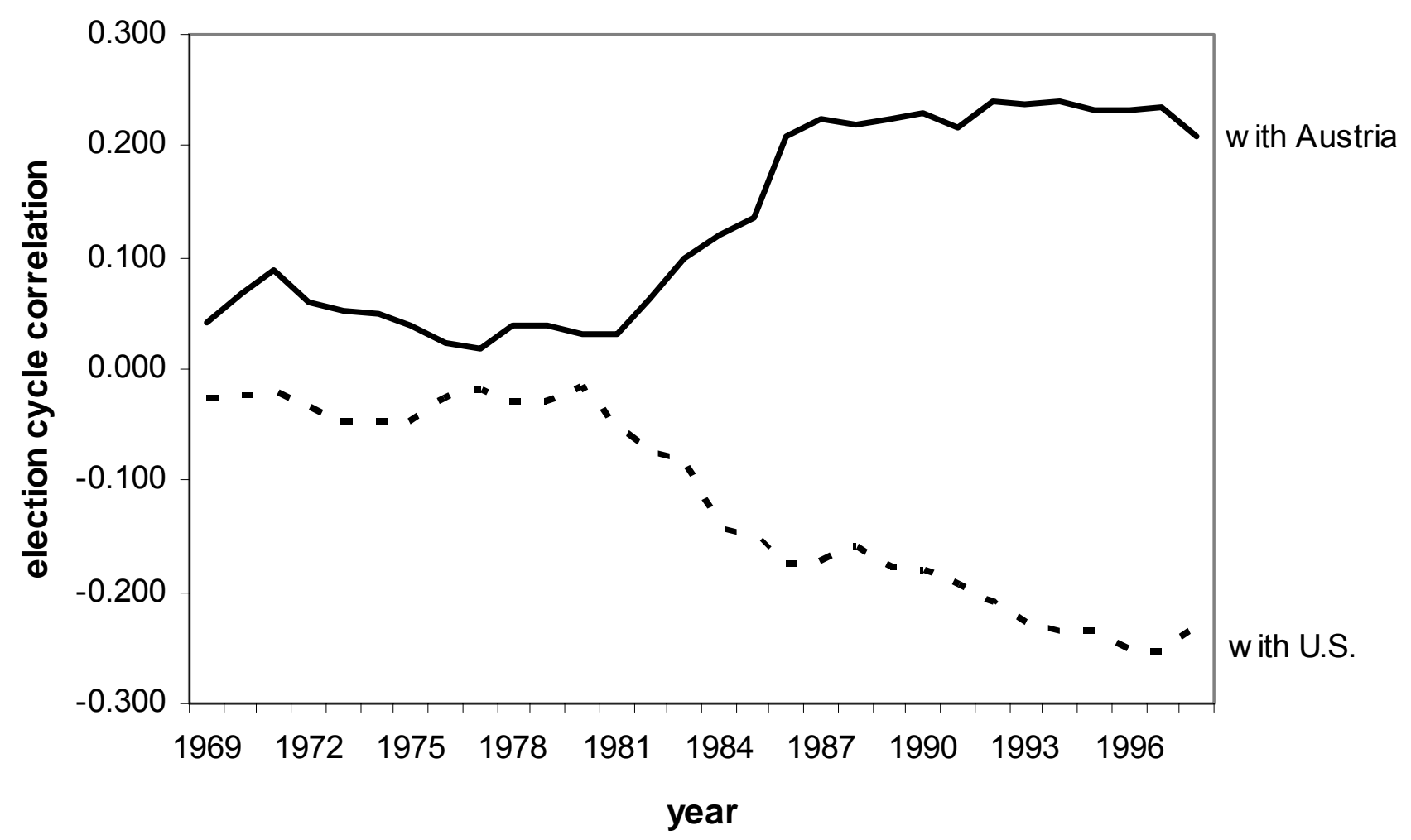

${ }^{29} 20$-year moving average. Austria, Denmark, Iceland, Ireland, Italy, Netherlands, United Kingdom. Greece and Spain omitted because of short democratic histories. No country correlated with itself. Each year represents the end of a 20 -year moving window. 